\title{
PENGELOLAAN SARANA PRASARANA PENDIDIKAN RESPONSIF GENDER : STUDI DI IAIN JEMBER
}

\author{
Nur Ittihadatul Ummah \\ Institut Agama Islam Negeri Jember \\ nur.ita34@yahoo.co.id
}

\begin{abstract}
Management of gender responsive educational facilities is an important issue that needs serious attention because the management of gender-responsive infrastructure can provide space to ensure the fulfillment of women's and men's rights based on their specific needs so as to create a sense of security and comfort for each user. IAIN Jember is required to pay attention to the specific needs of men and women so that dominance does not occur, does not cause difficulties for certain sexes in the use of infrastructure. Indicators of gender responsive infrastructure include the provision of separate toilets, child care and nursing rooms, provision of closed ablution places, closed prayer rooms, ideal $17 \mathrm{~cm}$ staircase facilities, CCTV and adequate lighting. The management of gender responsive educational facilities is needed to realize gender justice and equality, support reproductive and cultural functions. This research uses a qualitative approach with the type of case study research. The technique of collecting data uses observation, interviens and document study. Data analysis using interactive analysis. The validity of the data used source triangulation and method triangulation. The results showed that: the prayer room for employees tends to be open so there is no privacy, there are wheelchairs for students with disabilities, and there is no separate toilet for male and female employees.
\end{abstract}

\section{Keywords: Educational Facilities, Gender Responsive, IAIN Jember}

\begin{abstract}
Abstrak
Pengelolaan sarana pendidikan responsif gender merupakan isu penting yang perlu mendapat perhatian serius karena pengelolaan prasarana tanggap gender dapat memberikan ruang untuk menjamin pemenuhan hak perempuan dan laki-laki berdasarkan kebutuhan spesifiknya sehingga ter-
\end{abstract}




\section{Nur Ittihadatul Ummah}

cipta rasa aman dan nyaman bagi setiap pengguna. IAIN Jember dituntut untuk memperhatikan kebutuhan khusus laki-laki dan perempuan agar tidak terjadi dominasi, tidak menyulitkan jenis kelamin tertentu dalam penggunaan infrastruktur. Indikator infrastruktur responsif gender antara lain penyediaan toilet terpisah, ruang penitipan anak dan menyusui, penyediaan tempat wudhu tertutup, mushola tertutup, fasilitas tangga ideal $17 \mathrm{~cm}$, CCTV dan penerangan yang memadai. Pengelolaan fasilitas pendidikan responsif gender diperlukan untuk mewujudkan keadilan dan kesetaraan gender, mendukung fungsi reproduksi dan budaya. Penelitian ini menggunakan pendekatan kualitatif dengan jenis penelitian studi kasus. Teknik pengumpulan data menggunakan observasi, wawancara dan studi dokumen. Analisis data menggunakan analisis interaktif. Validitas data menggunakan triangulasi sumber dan metode triangulasi. Hasil penelitian menunjukkan bahwa : mushollah untuk karyawan cenderung terbuka sehingga tidak ada privasi, terdapat kursi roda bagi mahasiswa difabel. Kursi roda ini berada di poli klinik kampus, dan tidak ada pemisahan toilet bagi karyawan laki-laki dan perempuan.

\section{Kata Kunci : Sarana Pendidikan, Responsif Gender, IAIN Jember}

\section{Pendahuluan}

Pemerintah Negara Indonesia memiliki landasan yuridis yakni melalui Instruksi Presiden (Inpres) No. 9 Tahun 2000 tentang pengarusutamaan gender (PUG) dalam pembangunan nasional, yang mengamanatkan seluruh pimpinan termasuk Perguruan Tinggi sesuai dengan tugas, fungsi dan kewenangannya masingmasing untuk melaksanakan strategi pengarusutamaan gender dalam pencapaian kesetaraan dan keadilan gender.

Isu gender dalam bidang pendidikan terjadi karena adanya kebijakan, program, serta kegiatan yang kurang memperhatikan perbedaan kebutuhan laki-laki dan perempuan. laki-laki dan perempuan memiliki kebutuhan yang berbeda dalam melakukan akses, partisipasi, kontrol dan manfaat. Terwujudnya pendidikan yang berkeadilan gender menuntut sarana dan prasarana yang peka dan 
Vol. 12, No. 2, Oktober 2019

p-ISSN:2086 -0749

e-ISSN:2654-4784

responsif gender. Untuk itu, diperlukan komitmen yang besar dari semua pihak yang terlibat dalam pendidikan.

Pengelolaan Sarana prasarana pendidikan responsif gender di institusi Agama Islam Negeri Jember (IAIN Jember) merupakan isu penting yang perlu mendapatkan perhatian serius karena pengelolaan sarana prasarana yang responsif gender dapat memberikan ruang untuk menjamin pemenuhan hak perempuan dan laki-laki berdasarkan kebutuhan spesifik masing-masing sehingga memunculkan rasa aman dan nyaman bagi setiap penggunanya.

IAIN Jember merupakan satu-satunya Perguruan Tinggi Agama Islam yang berstatus Negeri setapal Kuda ini. Sebagai lembaga pendidikan Tinggi Islam, IAIN Jember dituntut memperhatikan kebutuhan spesifik laki- laki dan perempuan dalam pengelolaan sarana prasarana pendidikan, sehingga tidak terjadi dominasi dalam pemanfaatan sarana prasarana pendidikan, tidak menimbulkan kesulitan pada jenis kelamin tertentu dalam penggunaan sarana prasarana, justru tersedianya sarana prasarana pendidikan dapat menunjang fungsi reproduksi dan kultural.

Pengelolaan sarana dan prasarana pendidikan responsif gender menjadi tugas dan tanggungjawab bersama, namun sebagian warga kampus memiliki pemahaman yang minim akan sarana prasarana yang responsif gender dengan beranggapan pemenuhan sarana prasarana responsif gender sebagai hal yang tidak penting. Untuk itu, perlu dikaji lebih dalam tentang pemenuhan hak dan perlindungan bagi perempuan sebagai acuan 


\section{Nur Ittihadatul Ummah}

bagi instansi, dalam rangka penyediaan sarana prasarana yang responsif gender. Pentingnya pengelolaan sarana prasarana responsif gender diperlukan untuk mewujudkan keadilan dan kesetaraan gender. Dalam hal ini akan diidentifikasi dan dianalisis dalam konteks akses, partisipasi, kontrol dan manfaat.

Sarana prasarana responsif gender dibutuhkan karena adanya kebutuhan spesifik laki-laki dan perempuan yang berbeda. Dengan demikian tidak ada satu jenis kelamin yang terabaikan hak-haknya, namun kenyataanya sarana dan prasarana yang ada masih belum sepenuhnya responsif gender. Berdasarkan indikator sarana prasarana responsif gender antara lain penyediaan toilet terpisah, tempat penitipan dan ruang menyusui/laktasi, penyediaan tempat wudhu dan mushalla yang tertutup dari laki-laki karena perempuan harus membuka auratnya saat berwudhu, serta fasilitas tangga dengan ukuran ideal anak tangga $17 \mathrm{~cm}$ ke bawah sehingga tidak menyulitkan bagi lansia dan ibu hamil serta adanya pemasangan CCTV dan pencahayaan yang memadai di ruang atau lokasi yang rawan terjadinya kejahatan, tetapi kenyataanya dari 6 indikator sarana prasarana responsif gender tersebut tidak semua terpenuhi. Adapun yang belum terpenuhi yaitu tempat penitipan anak, ruang menyusui/laktas, CCTV dan pencahayaan yang memadai di ruang atau lokasi yang rawan terjadinya kejahatan. Padahal fasilitas tersebut sangat penting dan dibutuhkan.

Sejalan dengan latar belakang masalah dan identifikasi masalah, maka rumusan masalah dalam penelitian ini diformulasikan sebagai berikut:

Bagaimana pengelolaan sarana prasarana pendidikan responsif gender di IAIN Jember dari sudut pandang dosen dalam aspek akses, partisipasi, kontrol, dan manfaat?; 
Vol. 12, No. 2, Oktober 2019

p-ISSN:2086 -0749

e-ISSN:2654-4784

(2) Bagaimana pengelolaan sarana prasarana pendidikan responsif gender di IAIN Jember dari sudut pandang mahasiswa dalam aspek akses, partisipasi, kontrol, dan manfaat?; (3) Bagaimana pengelolaan sarana prasarana pendidikan responsif gender di IAIN Jember dari sudut pandang karyawan dalam aspek akses, partisipasi, kontrol, dan manfaat?

Kata pengelolaan atau manajemen merupakan suatu istilah kontemporer yang dikenal dan digunakan oleh berbagai organisasi. Dalam Kamus Besar Bahasa Indonesia, dijelaskan bahwa kata manajemen merupakan proses penggunaan sumber daya secara efektif untuk mencapai sasaran ${ }^{1}$.

Sudjana dalam buku Engkoswara dan Komariah mengemukakan bahwa pengel-

${ }^{1}$ Kamus Besar Bahasa Indonesia. 2000. Jakarta: Balai Pustaka), h. 623 olaan atau manajemen adalah rangkaian dari berbagai aktivitas yang wajar dilakukan dalam suatu organisasi berdasarkan normanorma yang telah ditetapkan dan pelaksanaannya memiliki hubungan dengan komponen yang lainnya ${ }^{2}$.

Keberadaan sarana dan prasarana mutlak dibutuhkan dalam proses pendidikan. Sarana prasarana merupakan komponen penting yang harus dipenuhi dalam pelaksanaan proses pendidikan. Proses pendidikan akan mengalami hambatan dan masalah yang sangat serius, bahkan bisa mengalami suatu kegagalan jika tidak didukung dengan sarana dan prasarana pendidikan yang memadai $^{3}$

2 Aan Komariah, Engkoswara, 2010, Administrasi Pendidikan, Bandung: Alfabeta), h. 86

3 Qomar, Mujamil, 2007, Manajemen Pendidikan Islam, (Jakarta: Erlangga), h. 170 


\section{Nur Ittihadatul Ummah}

Pengelolaan sejatinya adalah proses mendayagunakan sumber daya untuk memperoleh tujuan sebab dengan adanya pengelolaan yang baik maka suatu organisasi akan bisa mencapai tujuan yang diharapkan. Salah satu yang perlu dikelola dalam organisasi termasuk lembaga pendidikan yakni sarana dan prasarana karena sarana prasarana merupakan bagian penting dalam menujang proses pembelajaran, tanpa adanya sarana dan prasarana yang mendukung, maka proses pendidikan tidak dapat berjalan secara optimal, oleh karena itu pengelolaan sarana dan prasarana sangat diperlukan untuk mewujudkan tujuan pendidikan.

Pada dasarnya pengelolaan sarana dan prasarana pendidikan memiliki beberapa prinsip secara umum yaitu: 1) Prinsip pencapaian tujuan, 2) Prinsip efisiensi, 3) Prinsip administratif, 4) Prinsip kejelasan tanggung jawab, 5) Prinsip kekohesian ${ }^{4}$.

Agar semua sarana dan prasarana pendidikan dapat memberikan kontribusi yang berarti pada jalannya proses pembelajaran maka hendaknya sarana prasarana pendidikan tersebut dikelola dengan dengan baik. Pengelolaan dalam sarana prasarana meliputi:

1) Perencanaan. Menurut Dwiantara dan Sumarto dalam ${ }^{5}$, menyebutkan bahwa perencanaan adalah kegiatan memikirkan, memperhitungkan, meneliti hingga merumuskan tindakan yang akan dilakukukan di masa yang akan datang, baik yang berkaitan dengan aktivitas pengadaan sarana prasaran, pengelolaan, penggunaan,

4 Matin \& Fuad, Nurhattati, 2016, Manajemen Sarana dan Prasarana Pendidikan, Jakarta: PT. Raja Grafindo Persada), h. 5

${ }^{5}$ Ahmad Nurabadi, Manajemen Sarana dan Prasarana Pendidikan, (Malang: Fakultas Ilmu. Pendidikan Universitas Negeri Malang, 2014), h. 8 
Vol. 12, No. 2, Oktober 2019

p-ISSN:2086 -0749

e-ISSN:2654-4784

pengorganisasian serta

kegiatan pengendalianya.

2) Pengadaan adalah serangkaian kegiatan untuk menyediakan sarana dan prasarana pendidikan yang sesuai dengan kebutuhan, baik berhubungan dengan jenis barang, spesifikasi barang, jumlah serta waktu dan tempat, harga dan sumber yang bisa dipertanggungjawabkan ${ }^{6}$

3) Inventarisasi merupakan kegiatan mencatat dan menyusun sarana dan prasarana secara teratur, tertib, rapi dan lengkap berdasarkan ketentuan yang berlaku ${ }^{7}$

4) Penyimpanan adalah kegiatan menyimpan saran dan prasarana pendidikan di suatu

${ }^{6}$ Suryosubroto, 2004, Manajemen Pendidikan Sekolah. Bandung: Remaja Rosdakarya), h. 116

7 Bafadal, Ibrahim, 2004, Manajemen Perlengkapan Sekolah: Teori dan Aplikasinya. Jakarta: PT. Bumi Aksara), h. 53

tempat agar kualitas dan kuantitasnya terjamin. Kegiatan menyimpan barang meliputi kegiatan menerima, menyimpan, dan nendistribusikan barang.

5) Penggunaaan merupakan proses pendayagunaan sarana dan prasarana. Sarana dan prasarana pendidikan harus jelas kegunaannya sehingga dapat dimanfaatkan dengan efektif dan efisien ${ }^{9}$

6) Pemeliharaan sarana prasraana adalah kegiatan mengurus dan mengatur sarana prasarana agar selalu dalam keadaan baik dan siap digunakan. Pemeliharaan mencakup segala upaya yang dilakukan secara terus menerus agar sa-

\footnotetext{
${ }^{8}$ Barnawi, 2012, Manajemen Sarana dan Prasarana Sekolah, Jogjakarta: Ar-Ruzz Media), h. 78

9 Bafadal, Ibrahim, 2004, Manajemen Perlengkapan Sekolah, h. 31
} 


\section{Nur Ittihadatul Ummah}

rana dan prasarana tetap dalam keadaan baik.

7) Pemusnahan atau penghapusana, yakni kegiatan menghilangkan sarana dan prasarana dari daftar inventarisasi.

Kata gender berasal dari bahasa Inggris yang berarti jenis kelamin dan $\operatorname{sex}^{10}$. Arti gender di sini berbeda jika dibandingkan dengan pendapat Fakih $^{11}$ yang mengartikan gender sebagai suatu sifat yang melekat pada laki-laki ataupun perempuan yang dikonstruksikan secara sosial maupun kultural.

Selanjutnya Santrock mengemukakan istilah gender dan seks memiliki perbedaan dari segi dimensi. Isilah seks (jenis kelamin) mengacu pada dimensi biologis seorang laki-laki dan perempuan, sedangkan gender mengacu pada

\footnotetext{
${ }^{10}$ Salim, Peter, 1991, Advance EnglishIndonesia Dictionary edisi ketiga. (Jakarta: Modern English Press), h.7

11 Fakih, Mansour, 2006, Analisis Gender dan Transformasi Sosial. (Yogyakarta: Pustaka Pelajar), h. 71
}

dimensi sosial-budaya seorang laki-laki dan perempuan ${ }^{12}$. Gender merujuk pada peranan dan tanggung jawab laki-laki dan perempuan yang diciptakan dalam keluarga, masyarakat dan budaya.

Dalam diskursus akademik seks diartikan sebagai sesuatu yang melekat secara given/kodrati yang tidak bisa dipertukarkan, misalnya laki-laki memiliki penis, jakala, dan produksi sperma, sementara perempuan memiliki rahim, produksi sel telur, payudara dan lain sebagainya. Sedangkan gender adalah atribut yang melekat pada lakilaki dan perempuan yang dikonstruksikan secara sosial maupun budaya $^{13}$.

Dari beberapa penjelasan mengenai seks dan gender di atas, dapat dipahami bahwa seks merupakan pembagian jenis kelamin berdasarkan dimensi biologis dan

\footnotetext{
${ }^{12}$ Santrock, J. W, 2002, Life Span Development: Perkembangan Masa Hidup. (Jakarta: Erlangga), h. 365

13 Sumbulah, Umi, 2008, Spektrum Gender: Kilasan Inklusi Gender di Perguruan Tinggi. Malang: UIN Malang Press), h. 5
} 
Vol. 12, No. 2, Oktober 2019

p-ISSN:2086 -0749

e-ISSN:2654-4784

tidak dapat diubah-ubah, sedangkan gender merupakan hasil konstruksi manusia berdasarkan dimensi sosial-kultural tentang laki-laki atau perempuan.

Manajemen merupakan unsur yang sangat strategis dalam penyelenggaraan perguruan tinggi. Berdasar perhatiannya terhadap masalah gender, manajemen perguruan tinggi dapat dibedakan menjadi tiga model, yaitu: kebijakan netral gender, kebijakan bias gender, dan kebijakan responsif gender ${ }^{14}$.

Kebijakan netral gender merupakan kebijakan yang dibuat tanpa mempertimbangkan perbedaan situasi dan kebutuhan antara laki-laki dan perempuan. Kebijakan bias gender adalah kebijakan yang mengandung

14 Abdullah, Amin, 2001, Kebijakan Kepemimpinan Perempuan dalam Institusi Perguruan Tinggi: Pengalaman UIN Sunan Kalijaga, h. 1 prasangka atau pertimbangan yang negatif terhadap perempuan atau laki-laki. Kebijakan responsif gender merupakan kebijakan yang dibuat dengan mempertimbangkan perbedaan kondisi dan kebutuhan antara laki-laki dan perempuan. Di antara gambaran dan indikasi adanya indikator untuk mengaplikasikan manajemen perspektif gender adalah:

a. Menerima dan memandang secara wajar perbedaan yang ada pada laki-laki dan perempuan, karena adanya penghormatan pada perbedaan termasuk wujud dari keadilan gender.

b. Mendiskusikan bagaimana cara merombak struktur masyarakat yang membedakan peran dan relasi antara laki-laki dan perempuan, serta berupaya menyeimbangkannya. 


\section{Nur Ittihadatul Ummah}

c. Meneliti kemampuan dan bakat masing-masing warga Negara, baik laki-laki maupun perempuan, untuk terlibat dalam membangun masyarakat, memecahkan problemproblemnya dan mempersiapkan masa depannya.

d. Memperjuangkan secara terus menerus hak asasi manusia, di mana gender merupakan salah satu bagian yang tak terpisahkan.

e. Mengupayakan perkembangan dan penegakan demokrasi dan pemerintahan yang baik dalam semua institusi masyarakat, dengan melibatkan perempuan dalam semua levelnya, dan

Pendidikan merupakan kunci bagi keadilan gender, karena pendidikan merupakan tempat masyarakat mentransfer normanorma, pengetahuan dan kemampuan mereka ${ }^{15}$.

15 Susilaningsih dkk, 2004, Kesetaraan Gender di Perguruan Tinggi Islam, Baseline
Gender sebagai istilah yang dianggap baru pada prinsipnya adalah proses membahasakan atau memberi simbol terhadap perilaku dan fenomena yang sesugguhnya telah lama ada dan berlaku di tengah kehidupan manusia. Adanya studi gender pada dasarnya bertujuan untuk mengurangi dan menghilangkan ketidakadilan gender tersebut. Dengan kata lain, studi gender hendak mewujudkan keadilan social, dan keadilan social tidak tidak dapat diwujudkan tanpa adanya keadilan gender dalam masyarakat.

Keadilan gender biasanya merujuk pada aplikasi keadilan social dalam hal pemberian kesempatan yang sama antara laki-laki dan perempuan. Keadilan di sini tidak berarti bahwa laki-laki dan perempuan adalah sama dalam segala hal, namun yang dimaksud

and Institusional Analysis for Gender Mainstreaming in LAIN Sunan Kalijaga. UIN Sunan Kalijga kerjasama dengan McGillIAIN- Indonesia Social Equity Project), h. 23 
Vol. 12, No. 2, Oktober 2019

p-ISSN:2086 -0749

e-ISSN:2654-4784

adalah bahwa pemberian suatu kesempatan atau akses tidak tergantung pada perbedaan jenis kelamin. Keadilan gender, dengan demikian, dapat diartikan bahwa laki-laki dan perempuan memiliki dan menikmati status yang sama. Laki-laki dan perempuan samasama memiliki kesempatan untuk merealisasikan hak-hak dan potensinya untuk memberikan kontribusi pada perkembangan politik, ekonomi, sosial, dan budaya, serta sama-sama dapat menikmati hasil dari perkembangan $\mathrm{itu}^{16}$.

Fasilitas yang responsif gender merupakan fasilitas pendidikan yang memberikan ruang untuk menjamin pemenuhan hak perempuan dan laki-laki berdasarkan kebutuhan spesifik masingmasing sehingga memunculkan

16 Susilaningsih dkk, 2004, Kesetaraan Gender di Perguruan Tinggi Islam, h. 15-16. rasa aman dan nyaman bagi setiap penggunanya. Indikator sarana prasarana responsif gender antara lain: (1) Penyediaan tempat penitipan anak, (2) Penyediaan ruang menyusui/laktasi, (3) Fasilitas tangga dengan ukuran ideal anak tangga $17 \mathrm{~cm}$ ke bawah, (4) Pemisahan Toilet, (5) Fasilitas tempat wudhu dan mushalla,

Pemasangan CCTV serta pencahayaan yang memadai di ruang atau lokasi yang rawan terjadinya kejahatan ${ }^{17}$.

Penelitian ini menggunakan pendekatan kualitatif dengan jenis penelitian studi kasus. Teknik mengumpulkan data dengan: (a) observasi; (b) wawancara; dan (c) studi dokumen. Analisis data menggunakan analisis interaktif

17 Djunaedi, Wawan Ida Rosyidah, Iklilah Muzayyanah Dini Fajriyah, 2014, Buku Panduan Perencanaan dan Penganggaran Responsif Gender (PPRG) Bidang Pendidikan Islam. Jakarta: Kementerian Agama Republik Indonesia Direktorat Jenderal Pendidikan Islam), h. 25 


\section{Nur Ittihadatul Ummah}

dengan keabsahan data menggunakan triangulasi sumber dan metode.

\section{Temuan Penelitian dan}

\section{Pembahasan}

1. Pengelolaan sarana prasarana pendidikan responsif gender di IAIN Jember dari sudut pandang dosen dalam aspek akses, partisipasi, kontrol, dan manfaat.

Pandangan dosen yang menilai bahwa pengelolaan sarana dan prasarana pendidikan di IAIN Jember belum responsif gender. Hal ini didasarkan pada indikator sarana prasaran pendidikan yang responsif gender. Beberapa sarana dan prasarana di IAIN Jember secara keseluruhan belum memperhatikan dan mempertimbangkan kebutuhan spesifik lakilaki dan perempuan sehingga dinilai belum responsif gender, selain itu indikator dari sarana prasarana semuanya belum 
Vol. 12, No. 2, Oktober 2019

p-ISSN:2086 -0749

e-ISSN:2654-4784

yang menyebutkan bahwa indikator sarana prasarana responsif gender antara lain: (1) Penyediaan tempat penitipan anak, (2) Penyediaan ruang menyusui/laktasi, (3) Fasilitas tangga dengan ukuran ideal anak tangga $17 \mathrm{~cm}$ ke bawah, (4) Pemisahan Toilet, (5) Fasilitas tempat wudhu dan mushalla tertutup, (6) Pemasangan CCTV serta Pencahayaan yang memadai di ruang atau lokasi yang rawan terjadinya kejahatan ${ }^{18}$.

Pengelolaan sarana prasarana responsif gender yaitu tersedianya sarana-prasarana yang mempertimbangkan kebutuhan berbeda antara laki-laki dan perempuan. Pemanfaatan saranaprasarana tidak terjadi dominasi atas dasar perbedaan jenis kelamin. Penggunaan sarana-

18 Djunaedi, Wawan Ida Rosyidah, Iklilah Muzayyanah Dini Fajriyah, 2014, Buku Panduan Perencanaan dan Penganggaran Responsif Gender, h. 23 prasarana tidak menimbulkan kesulitan pada jenis kelamin tertentu. Tersedia sarana-prasarana untuk menunjang fungsi reproduksi dan kultural, misalnya: tempat penitipan anak, kamar mandi terpisah, dan transportasi.

Selain itu dosen berpandangan terkait aspek akses, partisipasi, kontrol dan manfaat yang menyebutkan bahwa: Aspek akses, tidak ada kendala artinya dosen laki-laki dan perempuan mendapatkan kesempatan yang dalam pengelolaan sarana prasarana pendidikan, dosen memperoleh sarana dan prasarana dengan kualitas yang sama dan peralatan dengan kualitas, jenis dan jumlah yang sesuai dengan proporsinya tanpa ada kesenjangan. Aspek partisipasi dan kontrol. Partisipasi dosen baik laki-laki maupun perempuan terbatas dalam arti dosen tidak dilibatkan secara langsung 


\section{Nur Ittihadatul Ummah}

dalam proses perencanaan, penganggaran, pelaksanaan, monitoring dan evaluasi dari pengelolaan sarana prasarana pendidikan di IAIN Jember, karena tidak bisa aktif ikut serta dalam proses perencanaan, penganggaran, pelaksanaan, monitoring dan evalusi sehingga untuk kontrol sarana prasarana pendidikan bukan berada di tangan dosen, namun lebih dominan kontrol ada pada pimpinan. Jumlah pimpinan yang ada saat ini lebih banyak pemimpin laki-laki dibandingkan pemimpin perempuan, baik dari senat, dekan, hingga kaprodi. Aspek manfaat yakni dosen lakilaki dan perempuan sama-sama bisa mendapatkan kesempatan untuk bisa mengembangkan potensinya di semua bidang tanpa ada diskriminasi. Disini dosen bisa merasakan manfaat dari adanya sebuah pembangunan, sehingga dosen laki-laki dan perempuan secara bersama-sama bisa mengambil manfaat dari pengel- olaan sarana prasarana pendidikan sehingga bisa mempertimbangkan dan sesuai dengan kebutuhan spesifik masing-masing.

Temuan data pada penelitian ini antara lain: Pertama, tidak ditemukannya ruang laktasi di semua unit kerja di IAIN Jember. Kedua, yaitu tangga yang ada memiliki ukuran yang bervariasi, dari $15 \mathrm{~cm}$ hingga $17 \mathrm{~cm}$ ke bawah, namun dari beberapa ukuran anak tangga yang ada sudah menunjukkan anak tangga ideal 17 $\mathrm{cm}$ ke bawah. Ketiga yaitu vakumnya tempat penitipan anak (TPA). Vakumnya tempat penitipan anak sebenarnya menjadi permasalahan tersendiri bagi ibuibu bekerja. Keempat, yaitu pada tubuh Pusat Studi Gender dan Anak mengalami kekosongan pemimpin. Kelima, yakni ditemukannya toilet dosen yang belum terpisah yaitu di kantor Fakultas Dakwah dan di kantor Fakultas Syari'ah. Bangunan dari kedua kantor tersebut merupakan 
Vol. 12, No. 2, Oktober 2019

p-ISSN:2086 -0749

e-ISSN:2654-4784

bangunan lama yang desainnya belum melakukan pemisahan toilet berdasarkan jenis kelamin.

2. Pengelolaan sarana prasarana pendidikan responsif gender di IAIN Jember dari sudut pandang mahasiswa dalam aspek akses, partisipasi, kontrol, dan manfaat

Pengelolaan sarana prasarana pendidikan responsif gender dimaksudkan untuk memenuhi kebutuhan perbedaan antara lakilaki dan perempuan. Dilihat dari sudut pandangan mahasiswa pengelolaan sarana dan prasarana pendidikan di IAIN Jember dianggap kurang responsif gender karena sarana prasarana yang responsif gender hanya ada sebagian dari beberapa sarana prasarana responsif gender. Selain itu mahaiswa menganggap pembangunan yang dilakukan kurang memperhatikan perbedaan antara laki-laki dan perempuan serta terdapat kerusakan beberapa fasilitas seperti toilet, proyektor, kipas angin, meja kursi mahasiswa sehingga menganggu aktivitas pembelajaran di kelas. Mahasiswa Manajemen Pendidikan Islam, Eko Wahyudi menjelaskan bahwa:

"Sarana prasarana di IAIN cukup baik, sebab sudah ada pembagian antara laki-laki dan perempuan untuk kamar mandi, dan menurut saya pembagian itu hanya ada di gedung $\mathrm{T}$, sedangkan di gedung $G$ masih belum ada pembagian antara laki-laki dan perempuan dengan begitu maka bisa dikatan pengelolaan sarana prasarana pendidikan di IAIN Jember kurang responsif gender. Untuk sarana di dalam kelas, di gedung $\mathrm{T}$ maupun di $\mathrm{G}$ masih kurang baik, sebab terdapat fasilitas penunjang proses perkuliahan yang mulai rusak dan tidak segera 


\section{Nur Ittihadatul Ummah}

diperbaiki oleh pihak terkait. Seperti halnya LCD atau proyektor yang di sebagian kelas masih ditemukannya dalam keadaan rusak, kipas anginnya juga rusak, Harusnya sarana dan prasarana ini diperhatikan, dipelihara, bagaimana sarana prasarana ini bisa menunjang pembelajaran, jadi harus sudah dikontrol bagaimana sarana prasarana yang baik sesuai dengan manajemen sarana prasarana". (Eko Wahyudi, Wawancara, 7 November 2019).

Apa yang disampaikan kedua mahasiswa ini sejalan dengan teori Sri Minarti tentang pemeliharaan sarana prasarana pendidikan adalah kegiatan untuk mengurus dan mengatur sarana dan prasarana untuk selalu dalam keadaan baik dan siap digunakan. Pemeliharaan mencakup segala upaya yang dilakukan terus menerus untuk mengusahakan agar sarana dan prasarana tetap dalam keadaan baik.
Mahasiswa menyebutkan pendapatnya terkait aspek akses, partisipasi, kontrol dan manfaat: Aspek akses semua mahasiswa dan mahasiswi mendapatkan peluang yang sama dalam pengelolaan sarana prasarana pendidikan, tidak ada masalah terkait dengan akses, karena semua mahasiswa samasama dapat porsi yang sama untuk bisa mengakses sarana prasarana pendidikan yang ada di kampus.Aspek partisipasi dan kontrol. Partisipasi mahasiswa dan mahasiswi sangat terbatas bahkan mahasiswa dan mahasiswi tidak pernah dilibatkan dalam proses perencanaan, penganggaran, pelaksanaan, monitoring dan evaluasi dari pengelolaan sarana prasarana pendidikan di IAIN Jember, karena sehingga berdampak kepada kontrol. Sejauh ini kontrol menjadi wewenang pimpinan. Aspek manfaat yakni mahasiswa dan mahasiswi sama-sama bisa mendapatkan kesempatan untuk bisa mengembangkan potensinya 
Vol. 12, No. 2, Oktober 2019

p-ISSN:2086 -0749

e-ISSN:2654-4784

di semua bidang tanpa ada diskriminasi, bersama-sama bisa mengambil manfaat dari pengelolaan sarana prasarana pendidikan yang ada.

Dari sini bisa disebutkan beberapa data temuan penelitian pada fokus dua antara lain: Pertama, toilet mahasiswa tidak terpisah di beberapa gedung antara lain di gedung $A, B, C, D, E, F$, G, H1-H23. Kedua yaitu kondisi musholla yang biasa digunakan sebagai tempat sholat bagi mahasiswa yang berada di gedung E, F, G, H. Ketiga yaitu kondisi tempat wudhu terbuka di mushollah belakang. Hal ini menambah kekhawatiran bagi perempuan untuk wudhu, karena perempuan harus membuka sebagian auratnya saat berwudhu. Keempat yaitu fasilitas smoking area yang sungguh sedikit yang tidak seimbang dengan jumlah perokok aktif, adapun smoking area terdapat di gedung T tepatnya di lantai 4 Fakultas Tarbiyah dan Ilmu Keguruan.

3. Pengelolaan sarana prasarana pendidikan responsif gender di IAIN Jember dari sudut pandang karyawan dalam aspek akses, partisipasi, kontrol, dan manfaat

Temuan penelitian pada fokus pengelolaan sarana prasarana pendidikan responsif gender di IAIN Jember dari sudut pandang dosen dalam aspek akses, partisipasi, kontrol, dan manfaat adalah sebagai berikut:

Karyawan memberikan argumenya tentang pengelolaan sarana prasarana pendidikan resposif gender di IAIN Jember. Menurut persepsi karyawan pengelolaan sarana prasarana pendidikan di IAIN Jember kurang responsif gender. Beberapa data 


\section{Nur Ittihadatul Ummah}

wawancara dengan karyawan yaitu:

"Sarana dan prasarana pendidikan responsif gender itu kan yang bisa digunakan baik untuk laiki-laki dan perempuan. Kalau di IAIN Jember masih kurang mencerminkan yang responsif gender karena di Fakultas dakwah saja kamar mandi (toiletnya) masih campur". (Edi, wawancara, 4 November 2019).

Sejalan dengan itu maka dapat dipahami bahwa fasilitas atau sarana prasarana pendidikan responsif gender yaitu pengelolaan sarana prasarana yang mempertimbangkan kebutuhan laki-laki dan perempuan. Sebagaiman menurut pendapat Djunaedi, Rosyidah dan Fajriyah dalam buku pedoman PPRG dalam bidang pendidikan yakni fasilitas yang responsif gender merupakan fasilitas pendidikan yang memberikan ruang untuk menjamin pemenuhan hak perempuan dan laki-laki berdasarkan kebutuhan spesifik masing-masing sehingga memunculkan rasa aman dan nyaman bagi setiap penggunan$\mathrm{ya}^{19}$.

Aspek akses semua karyawan, baik laki-laki maupun perempuan mendapatkan kesempatan atau peluang yang sama dalam pengelolaan sarana prasarana pendidikan. Semua bisa mengakses sarana prasarana pendidikan yang ada tidak tanpa ada kesenjangan dan perbedaan karena semua dapat porsi yang sama untuk bisa melakukan askes terhadap sarana prasarana pendidikan yang ada. Aspek partisipasi dan kontrol. Karyawan tidak memiliki pastisipasi berarti dalam arti partisipasi karyawan sangat terbatas bahkan karyawan tidak pernah dilibatkan dalam proses perencanaan, penganggaran, pelaksanaan, monitoring dan evaluasi dari pengelolaan sarana prasa-

19 Djunaedi, Wawan Ida Rosyidah, Iklilah Muzayyanah Dini Fajriyah, 2014, Buku Panduan Perencanaan dan Penganggaran Responsif Gender, h. 25 
Vol. 12, No. 2, Oktober 2019

p-ISSN:2086 -0749

e-ISSN:2654-4784

rana pendidikan yang ada di kampus IAIN Jember, hal ini berefek pada control karyawan akan pengelolaan sarana prasarana pendidikan di IAIN Jember. Sejauh ini control merupakan otoritas pimpinan.Aspek manfaat yakni karyawan sama-sama bisa mendapatkan manfaat dari pengelolaan sarana prasarana pendidikan yang ada. Dari adanya pengelolaan sarana prasarana pendidikan responsif gender karyawan mendapatkan manfaat yang berarti yaitu merasakan kenyamanan dan keamanan.

\section{Simpulan}

Dari sini dapat disebutkan beberapa temuan penelitian pada fokus tiga antara lain: Pertama, mushollah untuk karyawan cenderung terbuka sehingga tidak ada privasi. Kedua yaitu terdapat kursi roda bagi mahasiswa difabel.
Kursi roda ini berada di poli klinik kampus. Siapapun yang membutuhkan kursi roda bisa memanfatkan kursi roda yang ada di poli klinik. Ketiga yaitu tidak ada pemisahan toilet bagi karyawan lakilaki dan perempuan yang di tempatkan di unit kerja institut, kepegawaian, Unit Pengembangan Bahasa (UPB), Teknologi Informasi dan Pangkalan Data (TIPD), Lembaga Penjaminana Mutu (LPM), Lembaga Pusat Penelitian dan Pengabdian Masyarakat (LP2M), Poli Klinik IAIN Jember, Perpustakaan IAIN Jember, Fakultas Syari'ah dan Fakultas Dakwah.

\section{Daftar Pustaka}

Abdullah, Amin. 2001. Kebijakan Kepemimpinan Perempuan dalam Institusi Perguruan Tinggi: Pengalaman UIN Sunan Kalijaga. 


\section{Nur Ittihadatul Ummah}

Anshor, Maria Ulfah. 2008. “Tantangan Kepemimpinan Perempuan di Tingkat Lokal". Jurnal Studi Gender dan Anak Yin Yang Vol. 3, No.1 JanJun.

Arikunto, Suharsimi. 2008. Manajemen Pendidikan. Yogyakarta: Aditya Media.

Bafadal, Ibrahim. 2004. Manajemen Perlengkapan Sekolab: Teori dan Aplikasinya. Jakarta: PT. Bumi Aksara

Barnaw. 2012. Manajemen Sarana dan Prasarana Sekolah. Jogjakarta: Ar-Ruzz Media. Engkoswara, dan Aan Komariah. 2010. Administrasi Pendidikan. Bandung. Alfabeta.

Djunaedi, Wawan Ida Rosyidah, Iklilah Muzayyanah Dini Fajriyah. 2014. Buku Panduan Perencanaan dan Penganggaran Responsif Gender (PPRG) Bidang Pendidikan Islam. Jakarta: Kementerian Agama Republik Indonesia Direktorat Jenderal Pendidikan Islam

Fakih, Mansour. 1996. Analisis Gender dan Transformasi Sosial, Cet I. Yogyakarta: Pustaka Pelajar.
Fakih, Mansour. 2006. Analisis

Gender dan Transformasi Sosial. Yogyakarta: Pustaka Pelajar.

Gunawan, Ary. 1996. Administrasi Sekolah: Administrasi Pendidikan Mikro. Jakarta: Rineka Cipta

Kamaluddi, Muhammad dan Rizki Budhi Suhara. 2018. "Analisis Sarana Prasarana dan Tingkat Literasi Media dalam Perspektif Gender: Studi Deskriptif pada Universitas di Kabupaten dan Kota Cirebon". Jurnal Signal Vol. 6 No. 1.

Kamus Besar Bahasa Indonesia. 2000. Jakarta: Balai Pustaka

Kementerian Riset Teknologi dan Pendidikan Tinggi, Jumlah Perguruan Tinggi Tahun 2017

Mardalis. 2009. Metode Penelitian: Suatu Pendekatan Proposal. Jakarta: Bumi Aksara.

Matin \& Fuad, Nurhattati. 2016. Manajemen Sarana dan Prasarana: Konsep dan Aplikasinya. Jakarta: PT. Rajagrafindo

Megasarim Rika. 2014. "Peningkatan Pengelolaan Sarana 
An-Nisa' : Jurnal Kajian Perempuan \& Keislaman

Vol. 12, No. 2, Oktober 2019

p-ISSN:2086 -0749

e-ISSN:2654-4784

dan Prasarana Pendidikan untuk Meningkatan Kualitas Pembelajaran di SMPN 5 Bukittinggi”. Jurnal Administrasi Pendidikan, Vol. 2 No. 1, Juni.

Miles, Mattew B. dan A. Michael Huberman. 2007. Analisis Data Kualitatif: Buku Sumber Tentang Metode-Metode Baru, terj.Tjetjep Rohendi Rohidi.Jakarta: UI-Press

Minarti, Sri. 2011. Manajemen Sekolah: Mengelola Lembaga Pendidikan secara Mandiri. Jogjakarta: ArRuzz Media

Moleong, Lexy J. 2010. Metodologi Penelitian Kualitatif. Bandung: PT Remaja Rosdakarya

Mosse, Julia Cleves 1994. Gender dan Pembangunan, terj. Hartian Silawati. Yogyakarta: Pustaka Pelajar.

Mulyono. 2008. Manajemen Administrasi dan Organisasi Pendidikan. Yogyakarta: ArRuzz Media
Munhanif, Ali. 2001. Mutiara Terpendam: Perempuan dalam Literatur Islam Klasik. Jakarta: Gramedia Pustaka Utama.

Nuruzzaman dalam Zumrodi. 2015. "Pendidikan SenSitif Gender dalam Islam: Telaah Paradigmatis dalam Sejarah intelektualisme Islam Indonesia". Palastren, Vol. 8, No. 2, Desember

Peraturan Menteri Pemberdayaan Perempuan dan Perlindungan Anak No 5 tahun 2015 tentang Urgensi Penyediaan Sarana Kerja yang Responsif Gender dan Peduli Anak di Tempat Kerja

Permendiknas, Standar Sarana dan Prasarana Pendidikan

Prastyawan. 2016. "Manajemen Sarana dan Prasarana Pendidikan". Jurnal Studi Keislaman, Vol. 6, No. 1, Maret.

Prihatin, Eka. 2011. Teori Administrasi Pendidikan. Bandung: Alfabeta 


\section{Nur Ittihadatul Ummah}

Qamaruddin Hidayat, Kata Pengantar, dalam Zaitunah Subhan. 1999. Tafsir Kebencian Studi Bias Gender dalam Tafsir Qur'an. Yogyakarta: LkiS

Qomar, Mujamil. 2007. Manajemen Pendidikan Islam. Jakarta: Erlangga

Rahayu, Suri Margi, Sutama. 2015. "Pengelolaan Sarana dan Prasarana Pendidikan Sekolah Menengah Pertama". Jurnal Varidika Vol. 27, No. 2, Desember.

Salim, Peter. 1991. Advance English-Indonesia Dictionary edisi ketiga. Jakarta: Modern English Press

Santrock, J. W. 2002. Life Span Development: Perkembangan Masa Hidup. Jakarta: Erlangga

Sugiono. 2017. Metode Penelitian Kualitatif. Bandung: Alfabeta

Sukmadinata, Nana Syaodih. 2007. Metode Penelitian Pendidikan. Bandung: Remaja Rosdakarya.

Sumbulah, Umi. 2008. Spektrum Gender: Kilasan Inklusi Gender di Perguruan Tinggi.
Malang: UIN Malang Press

Suryosubroto. 2004. Manajemen Pendidikan Sekolah. Bandung: Remaja Rosdakarya.

Susilaningsih dkk. 2004. Kesetaraan Gender di Perguruan Tinggi Islam, Baseline and Institusional Analysis for Gender Mainstreaming in IAIN Sunan Kalijaga. UIN Sunan Kalijga kerjasama dengan McGill-IAINIndonesia Social Equity Project.

Undang-Undang Nomor $12 \mathrm{Ta}$ hun 2012 tentang Pendidikan Tinggi

www.komnasperempuan.go.id

www.pendis.kemenag.go.id 